\title{
Return to Freedom: Governance of Fair Innovation Ecosystems
}

\author{
Hans Akkermans, Jaap Gordijn, and Anna Bon
}

\begin{abstract}
The Vienna Manifesto on Digital Humanism attaches great importance to the innovation processes shaping the digital society. The digital humanism question we pose in this chapter is: if innovation is a shaping force, can it itself be shaped by humans and based on human values of a just and democratic society? Nowadays, innovation is commonly theorized in policy and academic research in terms of ecosystems. Although this framing makes room for multiple stakeholders and their interaction, it is limited as it still positions innovation as a natural process. Thus, it underplays the human value and societal design dimensions of technosocial innovation. We discuss some ideas and proposals for the governance of digital innovation ecosystems such that they are fair and equitable. Design-for-fairness has as its basis a just and democratic societal conception of freedom.
\end{abstract}

\footnotetext{
H. Akkermans $(\bowtie)$

w4ra.org, Vrije Universiteit Amsterdam, Amsterdam, The Netherlands

University for Development Studies UDS, Tamale, Ghana

e-mail: Hans.Akkermans@akmc.nl

J. Gordijn

Vrije Universiteit Amsterdam, Amsterdam, The Netherlands

The Value Engineers BV, Soest, The Netherlands

e-mail: jaap@thevalueengineers.nl
}

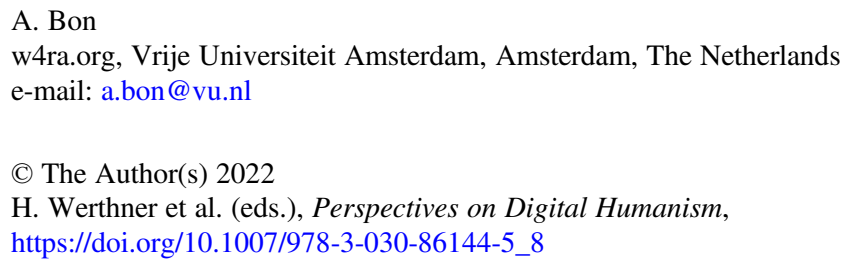




\section{The Vienna Manifesto and Innovation}

The Vienna Manifesto on Digital Humanism ${ }^{1}$ opens by quoting Tim Berners-Lee, the inventor of the World Wide Web, in that "the system is failing" (Berners-Lee 2018). Next, it states that "while digitalization opens unprecedented opportunities, it also raises serious concerns. (...) Digital technologies are disrupting societies and questioning our understanding of what it means to be human. The stakes are high and the challenge of building a just and democratic society with humans at the center of technological progress needs to be addressed with determination as well as scientific ingenuity. Technological innovation demands social innovation, and social innovation requires broad societal engagement."

The Vienna Manifesto emphasizes the importance of innovation processes, as innovation is seen as shaping the emerging digital society. A humanist key question is then: if innovation is a shaping force, can it itself be shaped for the purpose of a more just and democratic society? If so, how?

\section{Innovation Ecosystems}

The traditional policy view on innovation that has been dominant for decades casts innovation foremost in terms of "invention" and subsequent "adoption" and spread of an innovative technology. The early editions of Everett M. Rogers' (2003) highly influential text Diffusion of Innovations reflect this view. The process of innovation is captured in terms of a metaphor borrowed from physics. Diffusion is interpreted (certainly where it concerns the received view in high-level policy making) as a relatively deterministic, mechanistic, and unidirectional phenomenon. The same physics metaphor also serves to establish order (not to say: hierarchy) in the process of research, starting from fundamental research, then applied research, to strategic research and, ultimately, technology development.

In recent years, it has become mainstream to frame the innovation process in the different terms of ecosystems, both in academic literature (Oh et al. 2016) and in policy (European Union 2020). This move embodies a significant change from the older policy framing of innovation. It has a clear metaphorical nature as well, however, borrowed not from physics but from biology. This change of metaphor has important consequences in several ways.

First, the process image, or high-level empirical model, of innovation changes. Rather than a mechanistic process of diffusion (with the famous "S-curve" of adoption $^{2}$ ), it posits an interactive dynamic of multiple "species," i.e., the various

\footnotetext{
${ }^{1}$ https://dighum.ec.tuwien.ac.at/dighum-manifesto/ (May 2019)

${ }^{2}$ The S-curve (Rogers 2003, Ch. 7) refers to the S-shaped cumulative distribution function of innovation adoption. It may be mathematically derived from a very simple imitation model for the spread of an innovation within a population or market.
} 
key actors and stakeholders in the innovation environment. This is commonly phrased as a coevolution, a notion also prominent in the Vienna Manifesto (cf. also Lee 2020; Nowotny et al. 2001). It is furthermore common to find process analyses not in terms of straightforward one-dimensional diffusion, but instead of nonlinear complex adaptive systems; see, for example, Rogers et al. (2005) and Bon (2020).

Second, the new metaphor of ecosystems is a significant break also in the policy sense. It points to simultaneous competitive as well as collaborative relationships in innovation, in contrast with neoliberal free market ideologies that only can see enterprise competition within their horizon. It acknowledges that innovation is a multi-actor process that is non-deterministic and coevolutionary. It furthermore permits a different view on who are the actual stakeholders in play. It changes the view on the role of government as enabler of innovation, but it also changes and extends the role of civil society and other players that have hitherto often been ignored or downplayed. The latter point has been made particularly explicit in science-and-society and science policy literature (Gibbons et al. 1994; Etzkowitz and Leidesdorff 2000; Nowotny et al. 2001; Carayannis and Campbell 2012) on new modes of knowledge production and the triple/quadruple university-industry-government-civil society helix organization of innovation in nations, regions, and ("smart") cities.

Nevertheless, the ecosystems metaphor as a way to understand innovation has important limitations. Although more flexible and open-ended than older physics metaphors, it still frames innovation as some kind of natural process (but now "ecological" rather than physics-mechanistic), which on its turn carries with it the (invalid) suggestion that its course is out of human hands and beyond human control.

Indeed, business and management literature on innovation has difficulty acknowledging the implication that, as a result of the fact that humans are part of the ecology as actors and stakeholders, innovation is human-designable (at least to some extent). It is very weak in discussing key normative aspects of innovation ecosystems. Who stands to benefit from (disruptive) innovation, and why? Who is in control, and for what purposes? These are important and unavoidable matters (in a democratic debate, that is) that are discussed in literature on social innovation, but typically from disciplines other than economics and business research, witness, for example (Manzini 2015). In other words, the innovation ecosystem concept needs to be humanized, and this can be achieved by explicating the governance dimension of digital technologies. 


\section{Governance: Ecosystems That Are Fair}

As a corrective to the "failing of the system," Berners-Lee (2018) calls for a "redecentralization" of the Web. In a coevolutionary view, this may involve both technology (e.g., SOLID ${ }^{3}$ ) and non-technology societal actions. Jairam et al. (2021) make an explicit distinction between a technology and how it is controlled, pointing out that the technology level and its governance level can have very different characteristics. For example, the Big Tech platforms rely on network "decentralized" technologies, but their governance level is in contrast strongly centralized, even monopolistic. These authors investigate blockchain technologies (such as Bitcoin, Corda, Ethereum, Tezos) and their industrial applications (e.g., smart energy scenarios such as peer-to-peer sustainable energy trading). They show that also here many forms of governance exist from highly centralized to decentralized (and often opaque).

The focus of this work is on the question how the governance of technologies can be decentralized. ${ }^{4}$ To this end, these authors introduce the notion of fair innovation ecosystems and propose a set of design principles for fair and equitable ecosystems. Decentralized ecosystems, as a realistic alternative for the Big Tech platforms, have a fair distribution of governance power, whereby fairness is defined along the following lines (Jairam et al. 2021):

(a) Participation. Fair governance ensures active involvement in the decisionmaking process of all who are affected and other parties with an interest at stake. It includes all participants interacting through direct or representative democracy. Participants should be able to do so in an unconstrained and truthful manner, and they should be well informed and organized so as to participate fruitfully and constructively.

(b) Rule of law. Equity: all participants have legitimate opportunities to improve or maintain their well-being. Agreed-upon legal rules and frameworks, with underlying democratic principles, are enforced impartially while guaranteeing the rights of people; no participant is above the rule of law.

(c) Effectiveness and efficiency. Fair governance fulfils societal needs by incorporating effectiveness while utilizing the available resources efficiently. Effective governance ensures that the different governance actors meet societal needs. Fully utilizing resources, without being wasted or underutilized, ensures efficient governance.

(d) Transparency. Information on matters that affect participants must be freely available and accessible. The decision-making process is performed in a manner that is clear for all by following rules and regulations. Transparency also

\footnotetext{
${ }^{3}$ SOLID is a web-decentralization project led by Berners-Lee, aiming at developing a technology platform for Social Linked Data applications that are completely decentralized and fully under users' control (https://inrupt.com/solid/).

${ }^{4}$ The importance of good governance is explicitly recognized in the United Nations' Sustainable Development Goals (SDGs) and is the core topic of SDG 16.
} 
includes that enough relevant information is provided and presented in easy to understand forms or media.

(e) Responsiveness. A responsive fair governance structure reacts appropriately and within a reasonable time frame toward its participants. This responsiveness stimulates participants to take part in the governance process.

(f) Consensus-oriented. Fair governance considers the different participants' viewpoints and interests before decisions are made and implemented. Such governance is defined as consensus-oriented because it aims to achieve a broad community consensus. In order to reach this wide consensus, a firm mediation structure, without any bias toward participants, should be in place.

(g) Accountability. Accountability is defined as responsibility or answerability for one's actions. Decision-makers, whether internal or external, are responsible for those who are affected by their actions or decisions. These decision-makers are morally or legally bound to clarify and be answerable for the implications and selected actions made on behalf of the community.

Proposals such as these lay out a strong program for design-for-fairness of digital technology and society governance. Fairness includes both process and outcome aspects. As we will see below, interesting and informative precursors exist also in the non-digital society, including its ecosystems.

\section{Governance and Conceptions of Freedom}

Vardi (2018) attributes the failing of the Internet system to a naive "hippie" notion of information freedom. ${ }^{5}$ In his view, information has as a result become a "commons, an unregulated shared public resource" which is subject to "The Tragedy of the Commons" (Hardin 1968). Hardin's view was that commons governance of shared resources is inevitably doomed to fail, leaving as alternatives only market and state forms of governance. He derived this from the neoclassical economics theoretical assumption that humans act as rational self-interested individual agents. His anticollective arrangement argument was welcomed by neoliberal economists who employed it to promote their ideas about free markets as key governance mechanism. ${ }^{6}$

\footnotetext{
${ }^{5}$ This led to a lot of debate in the Communications of the ACM. In light of the discussion above and in the remainder of this article, one may perhaps say that hippie naiveté is in assuming that a decentralized technology effortlessly leads to a governance regime that is similarly decentralized. Quod non. This technology-driven mistake is perhaps more understandable upon realizing that an earlier generation of scientists concerned about societal impacts of science were dealing with highly centralized technologies such as the atom bomb. See, e.g., Bernal $(1939,1958)$, physics professor at Birkbeck College in London and a founding father of the field now known as Science, Technology, and Society (STS).

${ }^{6} \mathrm{An}$ interesting irony here is that Hardin's article has generally been received as supporting free market ideas, but Hardin was in fact writing about overpopulation and argued for the need of state
} 
Hardin's argument was a general theoretical one. Ostrom $(1990,2010)$, however, deconstructed and dismantled it in an evidence-based way, through a large international set of detailed empirical case studies and extensive field research. ${ }^{7}$ Her work makes clear that successful commons are widespread but are not at all "unregulated" (or free) as a shared resource. Generally, they are characterized by governance arrangements that consist of a complex array of participatory and "grassroots" democratic agreements, possibly mixed with market mechanisms as well as forms of state regulation. Ostrom's work gave rise to a theory of what she calls "polycentric governance," formulating a set of general conditions and design principles for commons-type arrangements to be successful. There are many successful and long-standing commons also in the digital world. Although due attention should be paid to the fact that digital resources have important differences from natural resources, there are interesting parallels with proposals such as those above regarding the governance of digital technology networks.

It is intriguing to observe that in virtually all discussions of governance issues, a concept of freedom is involved, although different and even conflicting ones, and often hidden in the background. ${ }^{8}$ Following De Dijn (2020), a prevalent conception of freedom today, adhered to by neoliberals, free marketeers, and libertarians, is that of limited state power. She describes this as a major and deliberate break with much older conceptions of freedom as developed in the Humanism and Enlightenment periods, where freedom is a collective concept and lies in the ability by the people to exercise control over the way in which they are governed - at root a democratic and participatory conception of freedom. In contrast, she traces back the leave-me-alone, I-want-to-do-what-I-like individualized conceptions of freedom to the antidemocratic and counterrevolutionary forces of the seventeenth and eighteenth centuries. ${ }^{9}$

A neoliberal conception of freedom reduces humans to individual, self-interested, utility-maximizing agents "freely" buying on a market. It is very much a consumptive and consumerist notion: market agents acquiring and consuming services on digital platforms. This neoliberal "the-world-is-flat" notion of freedom is indeed universal ("global") but in a fully undifferentiated and uniform ("flat") way. In contrast, the societal conception of freedom pointed at here is a productive notion: it is one of citizenship that co-creates the society we (hope to) live in. It is cosmopolitan but acknowledges that freedom is contextualized (Harvey 2009; Stuurman, 2017), with due recognition of the many different and overlapping

coercion, even to the point that he supported China's one-child policy. In contemporary digital society terms, he was arguing not for surveillance capitalism, but for the surveillance state.

${ }^{7}$ Elinor Ostrom received the Nobel Prize for Economics for this work in 2009. Not only was she the first woman to receive this prize, she was a political scientist rather than economist, leading to surprise in some economist quarters.

${ }^{8}$ As an interesting global example, Sen (1999) describes Development as Freedom. Chapter 5 of his book in particular displays that the underlying conception of freedom boils down to a neoliberal market one.

${ }^{9}$ It is tempting to add that the Big Tech power monopolies of today demonstrate that the neoliberal conception of freedom itself turns out to be Hayek's "road to serfdom." 
spheres and networks of human activities and relationships - including from the standpoint of the individual and their identity.

In the digital society, proper value-based digital governance (European Union 2020) is a return to freedom: the democratic and participatory freedom of Humanism and Enlightenment. Science and innovation policy has again to move forward, from the ecosystem helix frame to a much more inclusive policy of fair digital ecosystems. It is today's urgent task to redesign freedom in a value-based way and put it into action for a human future of our digital society.

\section{References}

Bernal, J.D. (1939) The Social Function of Science. London, UK: Routledge.

Bernal, J.D. (1958) World Without War. London, UK: Routledge \& Kegan Paul. 2nd edn 1961. ISBN 978-0-429-28245-4

Berners-Lee, T. (2018) ACM Turing Award Lecture, given at the 10th ACM Web Science Conference on 29 May 2018 in Amsterdam. The video of the Turing Award Lecture is available at the acm.org website: https://amturing.acm.org/vp/berners-lee_8087960.cfm. The Turing Award is considered to be the Nobel Prize for Informatics.

Bon, A. (2020) Intervention or Collaboration? Redesigning Information and Communication Technologies for Development. Amsterdam, The Netherlands: Pangea. ISBN 9789078289258. Open Access pdf version https:/w4ra.org/publications/

Carayannis E.G. and Campbell, D.F.J. (2012) Mode 3 Knowledge Production in Quadruple Helix Innovation Systems. New York, NY, USA: Springer. SpringerBriefs in Business 7. ISBN 9781461420613

De Dijn, A. (2020) Freedom: An Unruly History. Cambridge, MA, USA: Harvard University Press. ISBN 9780674988330

Etzkowitz, H. and Leidesdorff, L. (2000) The Dynamics of Innovation: from National Systems and "Mode 2" to a Triple Helix of University-Industry-Government Relations. Research Policy Vol. 29 , pp. $109-123$

European Union (2020) Berlin Declaration on Digital Society and Value-Based Digital Government. Signed at the ministerial meeting of the Council of the European Union on 8 December 2020. https://ec.europa.eu/isa2/sites/default/files/cdr_20201207_eu2020_berlin_declaration_ on_digital_society_and_value-based_digital_government_.pdf

Gibbons, M., Limoges, C., Nowotny, H., Schwartzman, S., Scott, P. and Trow, M. (1994) The New Production of Knowledge: The Dynamics of Science and Research in Contemporary Societies. London, UK: Sage. ISBN 0-8039-7794-8

Hardin, G. (1968) The Tragedy of the Commons. Science Vol. 162 No. 3859 (13 December 1968), pp. $1243-1248$

Harvey, D. (2009) Cosmopolitanism and the Geographies of Freedom. New York, NY, USA: Columbia University Press. ISBN 9780231148467

Jairam, S., Gordijn, J., Torres, I., Kaya, F. and Makkes, M. (2021) A Decentralized Fair Governance Model for Permissionless Blockchain Systems. In Proceedings of the International Workshop on Value Modelling and Business Ontologies (VMBO 2021), Bolzano, Italy, March 4-5, 2021. http://ceur-ws.org/Vol-2835/paper3.pdf

Lee, E.A. (2020) The Coevolution: The Entwined Futures of Humans and Machines. Cambridge, MA, USA: MIT Press. ISBN 9780262043939

Manzini, E. (2015) Design, When Everybody Designs: An Introduction to Design for Social Innovation. Cambridge, MA, USA: MIT Press. ISBN 9780262028608 
Nowotny, H., Scott, P. and Gibbons, P. (2001) Re-Thinking Science. Cambridge, UK: Polity Press. ISBN 0-7456-2608-4

Oh, D.-S., Phillips, F., Park, S., Lee, E. (2016) Innovation Ecosystems: A Critical Examination. Technovation Vol. 54, pp. 1-6

Ostrom, E. (1990) Governing the Commons: The Evolution of Institutions for Collective Action. Cambridge, UK: Cambridge University Press. ISBN 9780521405997

Ostrom, E. (2010) Beyond Markets and States: Polycentric Governance of Complex Economic Systems. American Economic Review Vol. 100, No. 3 (June 2010) pp. 641-672. Revised version of the Nobel Prize Lecture, 2009.

Rogers, E. M. (2003) Diffusion of Innovations. 5th edn. New York, NY, USA: Free Press

Rogers, E. M., Medina, U. E., Rivera, M. A, Wiley, C. J. (2005) Complex Adaptive Systems and the Diffusion of Innovations. The Innovation Journal Vol. 10 (No. 3), article 3, pp. 1-25

Sen, A. (1999) Development as Freedom. Oxford, UK: Oxford University Press. ISBN 9780192893307

Stuurman, S. (2017) The Invention of Humanity - Equality and Cultural Difference in World History. Cambridge, MA, USA: Harvard University Press. ISBN 9780674971967

Vardi, M.Y. (2018) How the Hippies Destroyed the Internet. Communications of the ACM Vol. 61 (No. 7, July 2018), p. 9

Open Access This chapter is licensed under the terms of the Creative Commons Attribution 4.0 International License (http://creativecommons.org/licenses/by/4.0/), which permits use, sharing, adaptation, distribution and reproduction in any medium or format, as long as you give appropriate credit to the original author(s) and the source, provide a link to the Creative Commons license and indicate if changes were made.

The images or other third party material in this chapter are included in the chapter's Creative Commons license, unless indicated otherwise in a credit line to the material. If material is not included in the chapter's Creative Commons license and your intended use is not permitted by statutory regulation or exceeds the permitted use, you will need to obtain permission directly from the copyright holder.

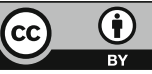

